MCLAGen, N.F. (1964) Biochemical Disorders in Human Disease, 2nd edn (Ed. R. H. S. Thompson and E. J. King). Churchill, London.

Nixon, W.C.W., Egeli, E.S., Laquer, W. \& Yakya, O. (1947) Icterus in pregnancy - A clinico-pathological study including liver biopsy. J. Obstet. Gynaec. Brit. Emp. 54,642 .

Peterson, R.D.A., Cooper, M.D. \& Good, R.A. (1965) The pathogenesis of immunological deficiency disease. Amer. J. Med. 38, 579.
Rafsky, H.A., Weingerten, M., Kriegler, C.I., Stern, K.G. \& Newman, B. (1950) Electrophoretic studies in liver disease. Gastroenterology, 14, 29.

Rosen, F.S. \& JANEWAY, C.A. (1966) The gamma globulins. III. The antibody deficiency syndromes. New Engl. J. 275, 709.

SHERLOCK, S. (1961) Disease of the Liver and Biliary System, 2nd edn. Blackwell Scientific Publications, Oxford.

SoothILL, J.F. (1967) Chemotherapy in the immunity deficiency syndrome. Postgrad. med. J. 43, Suppl. p. 64. Souire, J.R. (1962) Hypogammaglobulinaemia. Proc. roy. Soc. Med. 55, 393.

\title{
Abnormalities of spleen and pancreas in trisomy D syndrome
}

\author{
G. P. Clein* \\ M.A., M.B., M.R.C.P.
}

\author{
M. J. Mitchinson \\ M.A., M.B., M.C.Path.
}

Departments of Medicine and Pathology, Cambridge University

Numerous abnormalities have been described in association with trisomy D (Patau et al., 1960 ; Smith et al., 1963) and include malformations of the brain, eyes, maxilla, heart and great vessels, and genito-urinary tract. Capillary haemangiomata and polydactyly complete what is now a fairly easily recognizable clinical syndrome. The regular association of these malformations with trisomy $\mathbf{D}$ is obviously of great significance in morphogenesis and clues to the role of the extra D chromosome must come initially from careful documentation of cases. For this reason we are describing an infant with trisomy $D$ syndrome to emphasize a further morphological featurenamely combined abnormalities of the spleen and pancreas.

\section{Case report}

Female infant; 38 weeks; normal delivery. Mother's age, 26 years; father's age, 27 years. Pregnancy was normal throughout. Findings at birth were: cleft palate with hare-lip, microphthalmia with colobomata, micrognathia and low-set ears. The infant was cyanosed and a loud systolic murmur was heard. There were extra vestigial digits on both hands and cutaneous capillary haemangiomata. The infant had a number of convulsions and apnoeic attacks and died after 3 days. The clinical diagnosis was trisomy $D$ syndrome.

\section{Cytogenetics}

Cytogenetic studies were performed according to the technique of Moorehead et al. (1960) on heart blood taken shortly after death. A total of

* Present address: Royal Victoria Infirmary, Newcastle upon Tyne, 1.

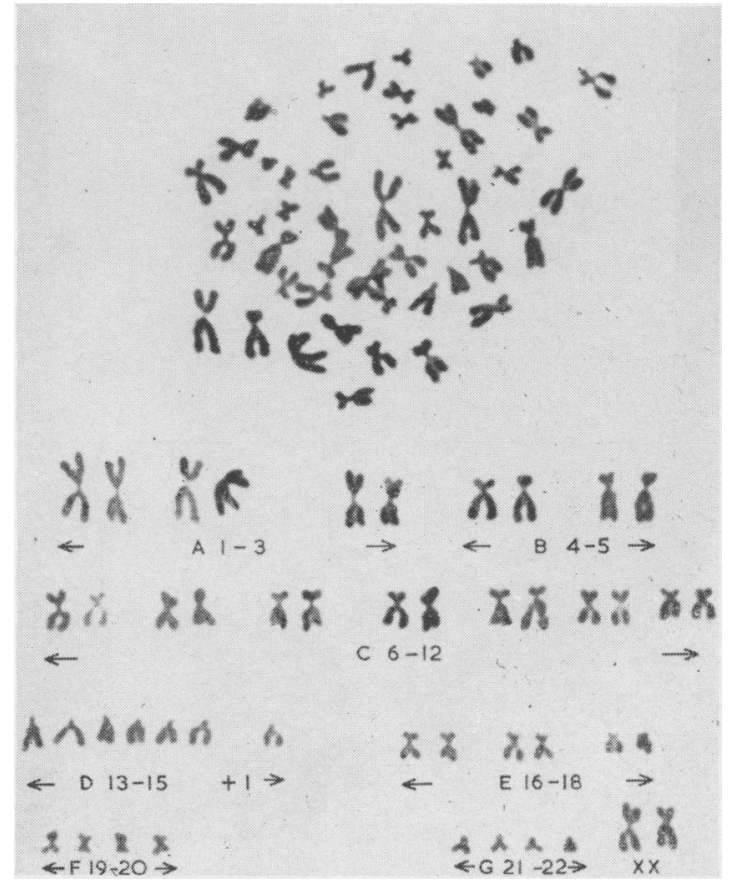

FIG. 1. Karyotype of present case.

forty cells was analysed. All showed forty-seven chromosomes, 45-XX-trisomy D (Fig. 1). Necropsy (P66.156)

Apart from the external abnormalities previously described other congenital malformations found were:

(1) Heart and great vessels. A left superior vena cava received the left jugular and subclavian veins and a left azygos vein, and drained directly 


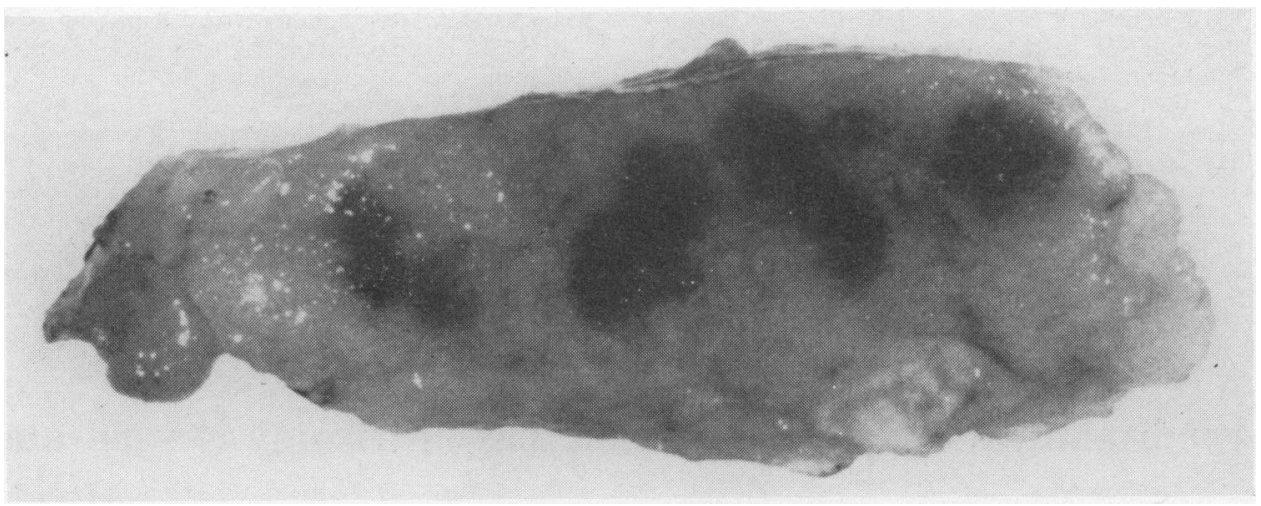

Fig. 2. Transverse section of tail of pancreas (unstained) to show cross-section of finger-like processes of splenic tissue.

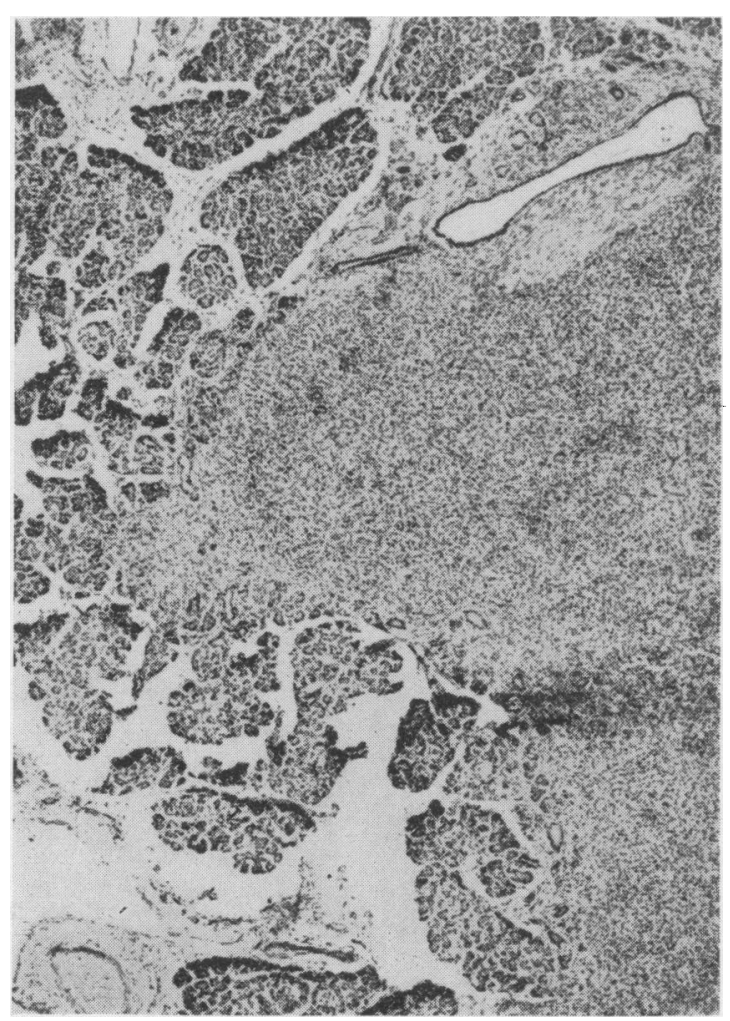

Fig. 3. Tail of pancreas to show process of splenic tissue. $H \& E, \times 36$.

into the postero-superior aspect of the left atrium which also received four normal pulmonary veins. The right atrium received the right superior vena cava; the inferior vena cava and hepatic vein, which passed through separate hiatuses in the diaphragm, drained separately into the right atrium. A large inter-atrial septal defect was present. Ebstein's anomaly was present; the infundi- bulum of the right ventricle was hypertrophied; the pulmonary valve was bicuspid. The pulmonary artery and its branches were normal; the ductus arteriosus was patent, though with a wrinkled lining. The mitral valve was normal. A small defect was present in the pars membranacea of the interventricular septum. The aortic valve was bicuspid but the coronary arteries were normal. Between the origin of the left subclavian artery and the entry of the ductus was a coarctation of the aorta. The aorta gave off a single umbilical artery at its? bifurcation.

(2) Bilateral accessory suprarenal cortical nodules beneath each renal vein.

(3) Bifid vagina, cervix and uterus.

(4) The spleen was thin and elongated (7.5 $\times$ $2.5 \times 2.0 \mathrm{~cm})$. There were no splenunculi. At its hilum the spleen was deeply infiltrated by pancreatic tissue and finger-like processes of splenic tissue extended deep into the tail of the pancreas (Fig. 2). Histological examination of the two organs showed intimate intermingling of the two tissues (Fig. 3). The spleen and pancreas were otherwise normal, histologically.

In addition to the congenital abnormalities there was a haemorrhage into the right suprarenal gland and bilateral tentorial tears with about $50 \mathrm{ml}$ of blood in the subdural space.

\section{Discussion}

The most unusual feature of this report is the abnormally long thin spleen, intermingling with the pancreas. A review of the reported cases of the trisomy $D$ syndrome reveals that abnormalities of the spleen or pancreas are recorded already in five instances (Table 1). In case 163 recorded by Smith et al. (1963) a nodule of ectopic splenic tissue extended into the tail of the pancreas and in their case 288 an accessory spleen contained histologically normal pancreas. Two other 
TABLE 1

\begin{tabular}{|c|c|c|c|}
\hline Authors & $\begin{array}{c}\text { Authors' } \\
\text { case } \\
\text { No. }\end{array}$ & Sex & Description \\
\hline $\begin{array}{l}\text { Smith et al. } \\
\text { (1963) }\end{array}$ & 163 & $\mathbf{F}$ & $\begin{array}{l}\text { A small nodule of ectopic splenic tissue was } \\
\text { found to extend from the lateral margin into } \\
\text { the tail of the pancreas }\end{array}$ \\
\hline $\begin{array}{l}\text { Smith et al. } \\
\text { (1963) }\end{array}$ & 288 & $\mathbf{F}$ & $\begin{array}{l}\text { Two small accessory spleens located along the } \\
\text { fundus of the stomach-one contained } \\
\text { histologically normal pancreas }\end{array}$ \\
\hline $\begin{array}{l}\text { Smith et al. } \\
\text { (1963) }\end{array}$ & 408 & $\mathbf{M}$ & $\begin{array}{l}\text { Accessory splenic tissue occurred adjacent to } \\
\text { the main spleen and above the left adrenal } \\
\text { gland }\end{array}$ \\
\hline $\begin{array}{l}\text { Connen et al. } \\
\quad \text { (1966) }\end{array}$ & 3 & $\mathbf{M}$ & $\begin{array}{l}\text { Spleen, } 11.5 \mathrm{~g} \text {, was abnormally long with } \\
\text { several small splenunculi at the distal end of } \\
\text { the pancreas }\end{array}$ \\
\hline $\begin{array}{l}\text { Snodgrass et al. } \\
\text { (1966) }\end{array}$ & 2 & $\mathbf{M}$ & Aberrant splenic tissue present in pancreas \\
\hline
\end{tabular}

cases record accessory ectopic splenic tissue, although this itself is not particularly remarkable. In case 3 of Connen, Erkman \& Metaxotou (1966) the spleen was long and thin and presumably resembled that of the present case.

Embryologically the finding in the present case is of some theoretical interest. The pancreas develops from dorsal and ventral buds arising from the duodenal endoderm. At the $12-\mathrm{mm}$ embryo stage the dorsal pancreatic bud extends cranially into the dorsal mesogastrium, where its tip is closely related to the spleen, which is developing as a localized mesodermal condensation in the dorsal mesogastrium. The two pancreatic buds fuse and with the process of rotation of the duodenum the space between the dorsal mesogastrium and posterior abdominal wall becomes obliterated and the adult relationships of the viscera are established. How the present abnormality has arisen one can only speculate. At the time the dorsal pancreatic bud is growing into the dorsal mesogastrium the forces which induce the regular condensation of mesogastrium into spleen are presumably distorted. With this disorganization isolated areas of mesogastrium in which the pancreas is growing develop into splenic tissue and, hence, surround and appear to infiltrate the organ.

Although this account does little more than describe in embryological terms rather than explain the abnormality, it does at least emphasize one important feature. The abnormalities that occur in trisomy $\mathbf{D}$ are distortions of the grosser morphogenetic movements in organogenesis rather than detailed abnormalities of cellular or tissue differentiation. Thus the principal findings are failure of closure of the optic cup, failure of the maxillary processes to meet and fuse, failure of division and rotation of the conus arteriosus, and mal-division of the Mullerian tract. Some exceptions to this generalization are immediately apparent such as polydactyly, haemangiomata, and the polymorphonuclear leucocyte abnormality (Huehns, Lutzner \& Hecht, 1964). However, the abnormality of pancreas and spleen here described accords with this generalization representing an abnormality in the genesis of the spleen at the period of the development of the pancreas and rotation of the gut.

\section{Summary}

An example is recorded of an unusual congenital abnormality of spleen and pancreas in the trisomy D syndrome. The relationship of this finding to other aspects of the syndrome is discussed.

\section{Acknowledgments}

We would like to thank Dr Douglas Gairdner for allowing us to publish this case. One of us (G.P.C.) is in receipt of an Elmore Research Studentship.

\section{References}

Conen, P.E., Erkman, B. \& Metaxotou, C. (1966) The "D" syndrome. Am. J. Dis. Childh. 111, 236.

Huehns, E.R., Lutzner, M. \& Hecht, F. (1964) Nuclear abnormalities in the neutrophils in $D^{1}$ (13-15) trisomy syndrome. Lancet, i, 589.

Moorehead, P.S., Nowell, P.C., Mellman, W.J., Battips, D.M. \& Hungerford, D.A. (1960) Chromosome preparations of leucocytes cultured from human peripheral blood. Exp. Cell Res. 20, 613.

Patau, K., Smith, D.W., Therman, E., Inhorn, S.L. \& WAGNER, H.P. (1960) Multiple congenital anomaly caused by an extra chromosome. Lancet, $\mathbf{i}, 790$.

Smith, D.W., Patau, K., Therman, E., Inhorn, S.L. \& DeMARS, R.I. (1963) The D 1 trisomy syndrome. J. Pediat. 62, 326.

Snodgrass, G.J.A.I., Butler, L.J., France, N.E., Crome, L. \& Russel, A. (1966) The "D" (13-15) trisomy syndrome: an analysis of 7 examples. Arch. Dis. Childh. 41, 250. 